Physical Geography; Cartography; Geographic Information Systems \& Spatial Planing

\title{
HYDROMORPHOLOGICAL STATE AND HABITAT QUALITY OF MOUNTAIN RIVERS ABOVE AND BELOW RESERVOIRS (THE POLISH CARPATHIANS)
}

DOI: http://dx.doi.org/10.18509/GBP.2016.18

UDC: $556.54: 502.175(438)$

\author{
Dr. Malgorzata Kijowska-Strugała \\ Dr. Lukasz Wiejaczka \\ Polish Academy of Sciences, Institute of Geography and Spatial Organization, Poland
}

\begin{abstract}
The paper presents the results of studies concerning the assessment of the hydromorphological state and habitat quality of two Carpathian rivers (the Wisłok and Ropa rivers), along sections situated above and below the reservoirs operating in the course of these rivers. The investigation was carried out based on the British method called River Habitat Survey (RHS). On the basis of the data collected, for each study section, synthetic indices HQA (Habitat Quality Assessment) and HMS (Habitat Modification Score), which enable assessment of the river habitat quality, were calculated. The analysis performed indicates that the sections of the Wisłok river considered, both above and below the Besko reservoir, fall into Class 2, which points to a good hydromorphological state and habitat quality. The Ropa river is characterised by moderate hydromorphological state (Class 3) above the Klimkówka reservoir and by good state (Class 2) below its location.
\end{abstract}

Keywords: hydromorphological state; habiat quality; rivers, reservoirs; Carpathians

\section{INTRODUCTION}

Hydromorphological state depends on a number of natural and anthropogenic elements, as well as on their mutual proportions. The higher the prevalence of natural elements, the better the habitat state of the river. Prevalence of anthropogenic components attests in turn to a marked transformation of the river environment by the man [1].

The relevance of the hydromorphological assessment of rivers together with any storage reservoirs along their courses stems from the need to determine the kind of changes that take place in the river environment after a reservoir is put into operation and to further monitor them. The impact of reservoirs on the individual biotic and abiotic elements of the natural environment is widely described and discussed in literature. The creation dam reservoirs is human intervention in the natural environment, causing, among other things: changes in the hydrological regime of the river, riparian ecosystems, the channel and valley morphology, the biodiversity of river species and water quality [2], [3]. The scale and extent of the impact of the reservoirs on the individual elements of the natural environment, both biotic and abiotic, may vary depending on the specifics of the natural environment and the parameters and age of the reservoir.

The purpose of the paper is to provide an assessment of the hydromorphological state and habitat quality of two Carpathian rivers (located within the same physico-geographical unit) above and below reservoirs. 


\section{RESEARCH AREA AND METHODOLOGY}

Two Carpathian rivers were selected for the investigation. The Wisłok river with the Besko reservoir and the Ropa river with the Klimkówka reservoir are located within the Low Beskids (Polish Western Carpathians) (Fig. 1). The Besko reservoir has been in operation since 1978, and the Klimkówka reservoir was put into operation in 1994 (Table 1). In comparison with other large Carpathian reservoirs, the Besko and Klimkówka reservoirs are small hydraulic structures. Table 1 shows a description of the individual reservoirs. The fundamental purpose for the construction of the Besko reservoir was to increase minimum flows in the Wisłok river below its location and thereby to protect biological life and provide a water intake for the Krosno town while for the Klimkówka reservoir it was to flood protection and to increase low flows in the Ropa river. In the case of the Besko reservoir, anti-flood protection is of secondary importance. The catchments of the Besko and Klimkówka reservoirs have approximate areas of $207 \mathrm{~km}^{2}$ and $210 \mathrm{~km}^{2}$ respectively.

Table 1. The basic parameters of studied reservoirs

\begin{tabular}{|l|c|c|}
\hline Reservoir & Besko & Klimkówka \\
\hline River & Wisłok & Ropa \\
\hline Establishment year & 1978 & 1994 \\
\hline Dam location in the river course & 172.8 & 54.4 \\
\hline Capacity [million $\left.\mathrm{m}^{3}\right]$ & 15.4 & 43.5 \\
\hline The area $\left[\mathrm{km}^{2}\right]$ & 1.31 & 3.06 \\
\hline Maximum depth $[\mathrm{m}]$ & 30 & 30 \\
\hline Guaranteed outflow $\left[\mathrm{m}^{3} \mathrm{~s}^{-1}\right]$ & 0.9 & 2.0 \\
\hline
\end{tabular}

The rivers along the course of which the reservoirs are located, even though they drain the area of the same physico-geographical unit (Fig. 1), due to the marginal location within the Low Beskids (transitional area between the Western and Eastern Carpathians), are characterised by different hydrological regimes.

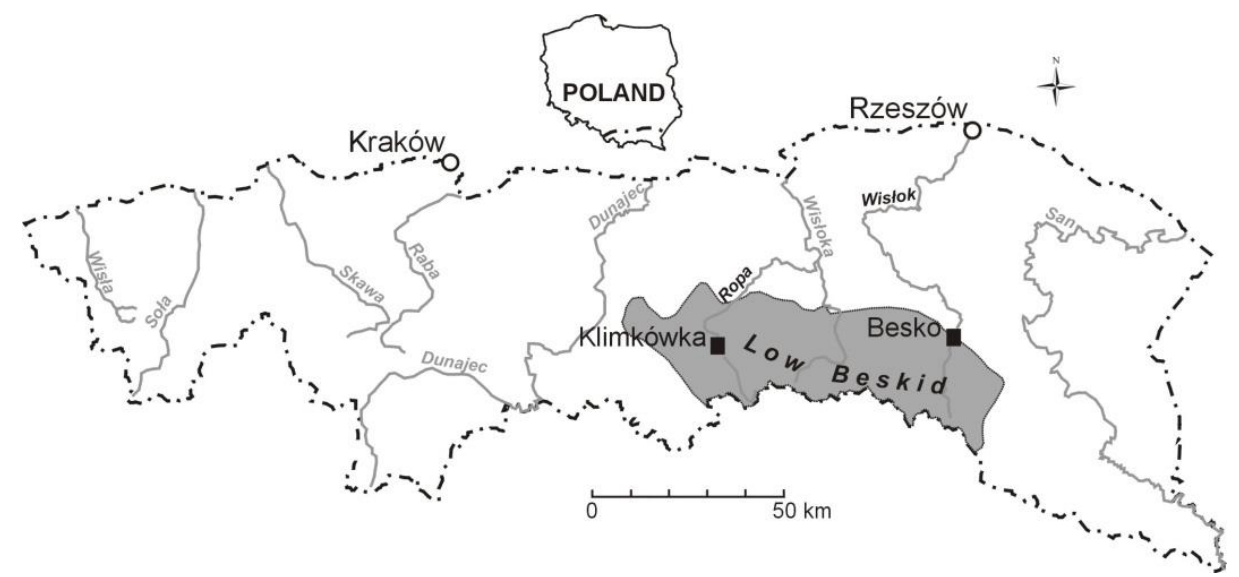

Figure 1. Locaction of the Wisłok and Ropa rivers with reservoirs in Polish Carpathians

The field investigation on the Wisłok and Ropa rivers was carried out in the summer of 2011, during a period of low water flows based on the RHS method. On each of the rivers under investigation, four study sections of a length of $0.5 \mathrm{~km}$ were designated. Two sections were located above the reservoirs at the distances of $1-1.5 \mathrm{~km}$ and $2-2.5 \mathrm{~km}$ from the backwater area of each reservoir, and the other two sections were situated in the distances of 0.5-1.0 km and 1.5-2.0 km downstream the water dams. 
The River Habitat Survey (RHS) method was designed in the early 1990s by the British Environment Agency. It is the most common method applied in Europe to assess the hydromorphological state of rivers [4], [5]. Guidelines for conducting research with the RHS method are contained in studies by [1], [6].

The investigation was carried out in two stages on selected $500 \mathrm{~m}$ sections of the rivers. In the first stage, characteristics of the basic morphological features of the channel and banks were made in 10 control profiles, spaced every $50 \mathrm{~m}$. In the second stage, a synthetic description of the entire study section was produced, taking into account the various morphological forms and transformations that had not been recorded in the previous stage. The material obtained made it possible to calculate the synthetic indices: the Habitat Quality Assessment (HQA) and the Habitat Modification Score (HMS), each being a resultant of many single basic parameters, and these in turn made it possible to assess the hydromorphological properties of the river in a numerical form.

\section{RESULTS}

\section{Hydromorphological state of the Wisłok and Ropa rivers above the reservoirs}

Along the investigation sections located on the Wisłok and Ropa rivers above the reservoirs, the basic material comprising the banks (left and right) of the river channels was loose, fine-grained material referred to as earth (crumbly) in the RHS method. In the case of the Wisłok river it occurred in 23 measured profiles (MP's) (with a total of 40 measured profiles), and for the Ropa River - 15 MP's. The Ropa river was characterised by a greater diversity of the material comprising the riverbanks. Among other things, riprap was recorded here and featured in 7 measured profiles.

In the majority of the measured profiles, in both rivers, natural components of the bank profile were not observed. Only in 5 measured profiles in the Wisłok river, there occurred erosive undercutting. Furthermore, an unvegetated point bar, an unvegetated and a vegetated side-bar and a severe bank undercutting were noted here. In the Ropa river, in 15 measured profiles an unvegetated side-bar was observed. Erosive bank undercutting and an unvegetated point bar were noted in 3 and 1 measured profiles respectively. Only in the channel of the Ropa river, bank modifications were noted in the form of reinforcements (by riprap) and reprofiling. Revetments on the Ropa river occurred in 6 MP's and reprofiling in 2 MP's. In the Wisłok river, bedrocks were predominant (10 MP's), and cobbles and gravel (diameter size 16-64 mm) on the Ropa river (13 MPs) in channel substrate. No presence of modifications of the channel bottoms were found in any of the measured profiles. Among the natural elements of the channel bottom that were distinguished in the course of the field investigation, exposed bedrock were predominant on the Wisłok river (10 MP's) and exposed boulders (protruding above the water surface) on the Ropa river (12 MP's). Above the investigated Carpathian reservoirs, two flow types were predominant: unbroken standing waves (rapid flow with short waves with glassy crests) and rippled (the surface of the water forms characteristic $1 \mathrm{~cm}$ high ripples that move along the river). Unbroken standing waves was predominant on the Wisłok river in $10 \mathrm{MP}$ 's, on the Ropa river - $15 \mathrm{MP}$ 's, and rippled on the Wisłok river in $8 \mathrm{MP}$ 's and on the Ropa river - 5 MP's. Land use within $5 \mathrm{~m}$ of the banktops of the analysed river channels above the reservoirs was dominated by broadleaf woodland in the case of the Wisłok river (30 MP's), and shrubs in the vicinity of the Ropa river channel (12 MP's). 
An essential element of land use of the Ropa river valley bottom in the immediate vicinity of the river channels was suburban development represented mainly by paved roads.

In the RHS method, vegetation structure is determined separately for the bank top (1 m zone beyond the banktop developing into a flood terrace) and on the face of the bank. At the tops of the riverbanks, simple structure of vegetation was predominant, characterised by occurrence of two or three types of vegetation comprising shrubs and/or trees (Wisłok river 24 MP's, Ropa river 19 MP's). No vegetation was observed on the bankface of the Wisłok river above the Besko reservoir. On the Ropa river, the predominant vegetation was of uniform structure (21 MP's). An essential element directly affecting the hydromorphological state of a river is aquatic vegetation. Diversity of aquatic vegetation provides good habitat conditions for invertebrates and other organisms. Above the reservoirs analysed, presence of mosses overgrowing material covering the channel beds was recorded. On the Ropa river, mosses were observed in all the profiles analysed, and in the Wisłok river, in 9. Additionally, in the Ropa river channel, structural algae were recorded, and emergent narrow-leaved plants in the Wisłok river.

\section{Hydromorphological state of the Wisłok and Ropa rivers below the reservoirs}

The basic material comprising the channel banks (left and right) of the Wisłok and Ropa rivers along the investigated sections located below the reservoirs was earth (Wisłok river in 26 MP's, Ropa river in 18 MP's), like in the sections above the reservoirs. Furthermore, bedrocks, cobbles and boulders were recorded on the Ropa river below the Klimkówka reservoir. Among the natural bank components observed along the investigation sections analysed on the Ropa river, occurrence of unvegetated side-bars was found (7 MP's), as well as unvegetated point bars and vegetated side-bars (4 MP's each), and also places of eroding cliff (2 MP's). Below the Besko reservoir, no natural morphological components of the bank, as distinguished in the RHS method, were observed. In the Ropa river channel, anthropogenic bank modifications were also observed in the form of resectioned (1 MP). On the Wisłok river, no bank modifications were observed along the sections analysed. In the rivers analysed below the reservoirs, the basic material comprising the channel bottom of the Wisłok river were bedrocks and cobbles (9 MP's each). In the case of the Ropa river, cobbles, boulders and gravel-pebbles in 10, 6 and 4 MP's respectively. Any presence of channel bottom modifications was not recorded in any of the measured profiles. Among the natural component elements of the bed that were observed during field investigation on the Wisłok river, bedrocks prevailed on the Wisłok river (10 MP's), and exposed boulders on the Ropa river (11 MP's) similarly as in the case of the investigation sections located above the reservoirs. From among the types of flow distinguished in the RHS method, rippled flow was recorded in the majority of the cross-section profiles on the Wisłok river (12 MP's). On the other hand, unbroken standing waves prevailed in cross-section profiles along the investigation sections located on the Ropa river (9 MP's). Additionally, in 4 profiles below the Klimkówka reservoir, smooth flow (slow laminar flow) was recorded.

Land use within $5 \mathrm{~m}$ of the banktops of the analysed river channels below the reservoirs was dominated by shrubs (15 MP's) and suburban development (14 MP's) in the case of the Ropa river. Along the Wisłok river channel, broadleaf/mixed woodland prevailed (26 MP's) as it was above the Besko reservoir. Below the Besko and Klimkówka reservoirs, at the banktops and bankfaces, simple structure of vegetation was predominant. Both on the Wisłok and the Ropa rivers, mosses were recorded in the channels below the reservoirs. Additionally, the Ropa river channel bottom was characterised by intensified 
presence of structural algae (20 MP's). In the Wisłok river channel, narrow- and broadleaved plants were recorded (in 6 and 1 MP's respectively). The occurrence of channel vegetation in the rivers below the water dams is the effect of the stabilisation of the flow and water level by the reservoirs.

Habitat quality of the Wisłok and Ropa Rivers based on the HQA and HMS indices Based on the investigation carried out, the HQA score was calculated, which is a synthetic sum total of the numerical values of elements in the natural environment. These elements affect the value of the HQA score to a varying degree (Fig. 2). Consideration of only the natural morphological elements of the channel and banks implied reduced significance of these elements for the overall value of the HQA index, especially in the case of the investigated sections of the Wisłok river above the Besko reservoir (Fig. 2). In the case of the Ropa river, the share of these morphological elements in the value of the HQA index amounted to $25 \%$ above the reservoir and $26 \%$ below it. It should be noted, however, that both in the case of the Wisłok and the Ropa rivers, above the reservoir there was noted an increase of the percentage share of the natural elements of the riverbank in the overall value of the HQA index with regard to the sections located below the reservoirs. A very important element for the assessment of the naturalness of the watercourse is the bankface and banktop vegetation. For both rivers, it has a high share in the value of the HQA index, with a higher percentage share recorded along the river sections above both of the reservoirs than below them (Fig. 2). A significant role in the RHS method is also played by tree coverages and the accompanying morphological elements. In the case of both rivers, a high share of these elements in the increase of the naturalness index of the river was caused by the presence of especially tree coverages (from 17\% - the Ropa river above the reservoir to $24 \%$ - the Wisłok river above the reservoir), which are valuable for the environment from the perspective of the RHS method.

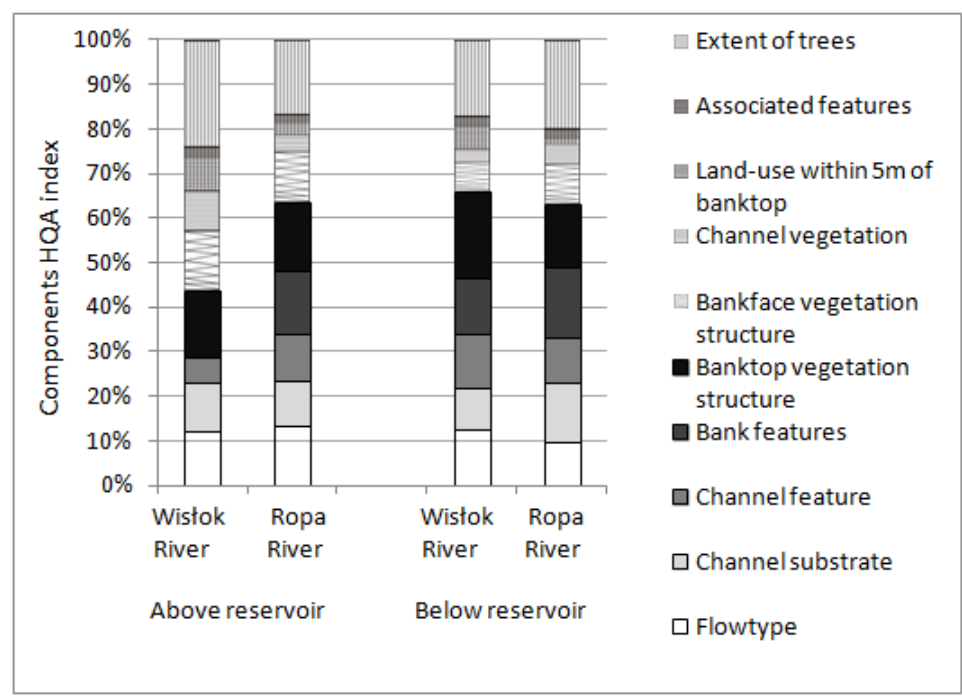

Figure 2. Components of Habitat Quality Assessment of analysed Wisłok and Ropa rivers above and below reservoir

The sections of both rivers that were located within the Besko and Klimkówka reservoirs were characterised by high values of the HQA index that is measure of the naturalness of a river. In the case of the Ropa river, these values fell within the range of 48-51, and for the Wisłok river in a lower range of 43-49 (Fig. 3). The greatest diversification of the 
HQA index value is associated with the Ropa river. Lower values were calculated for the river sections located above the Klimkówka reservoir in relation to the sections below the reservoir. This results from a larger number and diversification of the natural morphological elements within the channel (vegetated mid-channel bars, unvegetated point bar) and the surroundings of the river below the Klimkówka reservoir. A reversed situation was observed in the case of the Wisłok river (Fig. 3).
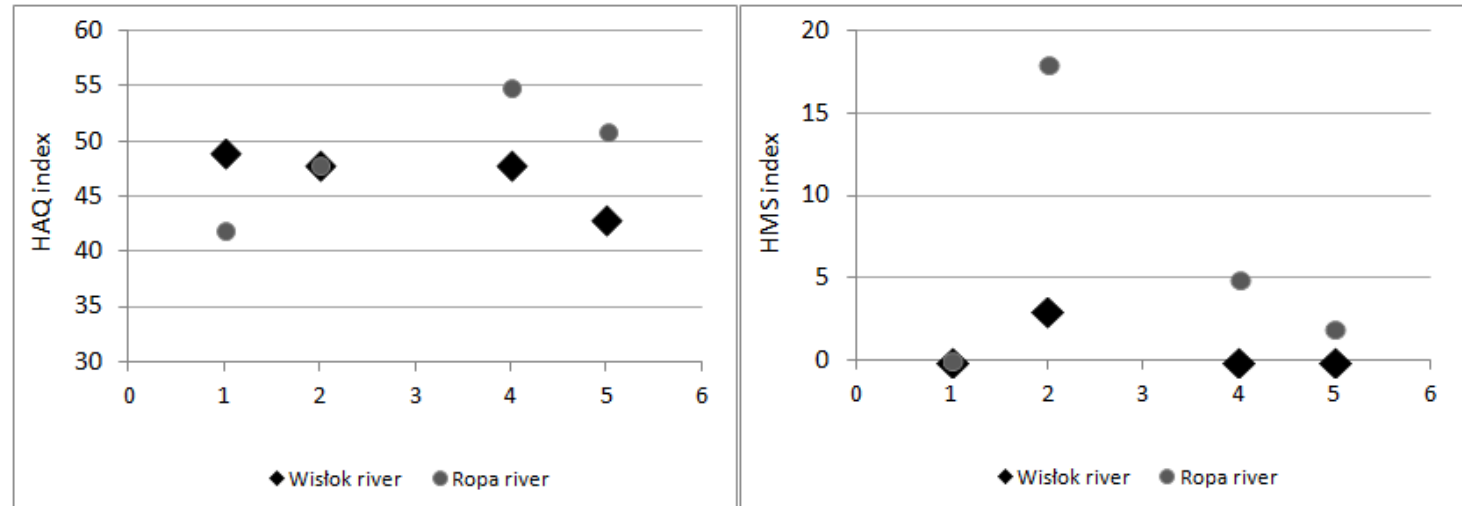

Figure 3. Changes in HQA and HMS index along the Wisłok and Ropa rivers channel course on 2 section above and 2 section below reservoirs ( 1 - 1st section above reservoir; 2 - 2nd section above reservoir, closer to the reservoir; 3 - 3rd section below reservoir, closer to the dam; 4 - 4th section below reservoir)

According to the classification by [7] (as modified by [8]) accommodated to Polish rivers, with regard to the diversity of the natural elements, the sections of the Wisłok river located above and below the Besko reservoir were classified into the moderately natural category. Likewise in the case of the investigation sections on the Ropa river above the Klimkówka reservoir. The measurement sections on the Ropa river below the reservoir were classified into the highest habitat quality class - natural (Table 2).

The HMS index values that define the degree of anthropogenic changes in the river hydromorphology were in the range 0-18 for the Ropa river and for Wisłok river were in a narrower and lower range of 0-3 (Fig. 3). It was established that the higher degree of transformation was characteristic for the sections located closest to the reservoirs (with the exception of the Wisłok river below the Besko reservoir where the HMS index value amounted to 0), (Fig. 3). Significantly higher values of the HMS index on the Ropa river as compared with the Wisłok river resulted from the presence of bank reinforcements and the resectioned of the banks for river engineering purposes. Additionally, they were influenced by the presence of a river crossing and a bridge. According to the classification by[7] (as modified by [8]) concerning the HMS index, the investigation sections above (mean HMS value $=2$ ) and below (mean HMS value $=0$ ) the Besko reservoir were classified as natural habitat. The investigation sections above the Klimkówka reservoir can be classified as little changed (mean HMS value $=9$ ) and the ones below as slightly changed (mean HMS value $=4)($ Table 2$)$.

The hydromorphological state of the test sections on the basis of the HQA as an index of habitat naturalness and the HMS as an index of habitat modification places the analysed Wisłok river sections above and below the Besko reservoir in Class 2, which indicates a good hydromorphological state. The Ropa river is characterised by a moderate hydromorphological state (Class 3) above the Klimkówka reservoir with a good hydromorphological state (Class 2) below the reservoir. 
Physical Geography; Cartography; Geographic Information Systems \& Spatial Planing

Table 2. Classification of the hydromorphological state of river based on the HQA and HMS scores [7] (modified by [8]): I - very good, II - good, III - moderate, IV - poor, V - bad.

\begin{tabular}{|c|c|c|c|c|c|}
\hline \multirow[b]{2}{*}{$\begin{array}{c}\text { Intervals points } \\
\text { HMS }\end{array}$} & \multicolumn{5}{|c|}{ Intervals points HQA } \\
\hline & $\begin{array}{l}\text { very natural } \\
(\mathrm{HQA} \geq 57)\end{array}$ & $\begin{array}{c}\text { natural } \\
(\mathrm{HQA}=50-56)\end{array}$ & $\begin{array}{c}\text { moderately } \\
\text { natural } \\
(\mathrm{HQA}=37-49)\end{array}$ & $\begin{array}{c}\text { low natural } \\
(\mathrm{HQA}=30-36)\end{array}$ & $\begin{array}{c}\text { little natural } \\
(\mathrm{HQA}<30)\end{array}$ \\
\hline $\begin{array}{c}\text { natural } \\
(\mathrm{HMS}=0-2)\end{array}$ & I & II & $\begin{array}{c}\text { II } \\
\text { (Wisłok river } \\
\text { above and below } \\
\text { reservoir) }\end{array}$ & III & III \\
\hline $\begin{array}{l}\text { slightly changed } \\
(\mathrm{HMS}=3-8)\end{array}$ & II & $\begin{array}{c}\text { II } \\
\text { (Ropa river } \\
\text { below reservoir) }\end{array}$ & III & III & IV \\
\hline $\begin{array}{l}\text { little changed } \\
(\mathrm{HMS}=9-20)\end{array}$ & III & III & $\begin{array}{c}\text { III } \\
\text { (Ropa river above } \\
\text { reservoir }\end{array}$ & IV & IV \\
\hline $\begin{array}{l}\text { much changed } \\
(\mathrm{HMS}=21-44)\end{array}$ & III & IV & IV & IV & V \\
\hline $\begin{array}{l}\text { highly changed } \\
\text { (HMS } \geq 45)\end{array}$ & IV & IV & V & V & V \\
\hline
\end{tabular}

\section{CONCLUSIONS}

The survey of the hydromorphological state and assessment of the habitat quality of the Wisłok and the Ropa rivers above and below reservoirs, carried out using the RHS method, has demonstrated that:

1) The rivers investigated, despite being located within the same physico-geographical unit (the Low Beskids) are characterised by mutually varied values of the HQA index of naturalness and the HMS index of habitat transformation.

2) With respect to the diversity of natural elements (the HQA index), the Wisłok river sections located above and below the Besko reservoir were classified as moderately natural habitat quality. Likewise in the case of the investigation sections on the Ropa river above the Klimkówka reservoir. The measurement sections on the Ropa river below the reservoir were classified as a higher class of habitat quality - natural. The HMS index values calculated above and below the Besko reservoir indicate natural river habitat while the investigation sections above the Klimkówka reservoir can be classified as moderately changed and as below as slightly changed.

3) The hydromorphological state of the test sections based on the HQA and HMS indices places the Wisłok river sections analysed above and below the Besko reservoir in Class 2 , which indicates a good hydromorphological state, and the Ropa river sections above the Klimkówka reservoir in Class 3 (moderate hydromorphological state) and those below to Class 2 (good hydromorphological state).

4) Investigation of the hydromorphological state of the Wisłok and the Ropa rivers using the RHS method has not shown a deteriorated habitat quality of the rivers below the location of the reservoirs with regard the upstream sections despite the fact that the particular abiotic and biotic elements of the environment had undergone changes. Habitat quality of the rivers studied, both above and below the reservoirs, depends mainly on the specificity of the natural environment of the area through which they flow. The better hydromorphological state of the river below the Klimkówka reservoir, in comparison with the conditions observed above the reservoir, is the result of a greater diversification of natural morphological elements of the channel. The quality of the river habitat below the 
Klimkówka reservoir was also affected by a lack of riverbank reinforcements. Reinforcements were present in the part of the river channel above the reservoir, but they were not directly related to the functioning of the reservoir. The Besko reservoirs is an example of a hydraulic structure that has no detrimental impact on the hydromorphological state of rivers. The studied river sections located both above and below the reservoirs were characterized by an almost natural habitat and a low degree of modification caused by humans.

The study has shown that the operation of the reservoirs does not always negatively impact the hydromorphological conditions of rivers, which is reflected by their habitat quality. It should be stressed, however, that the precise determination of the impact of the reservoirs on the hydromorphological state of the rivers below their location is impeded due to the fact that the reservoirs concerned mainly affect such changes in the river hydrological regime that are not taken into account in the RHS method. Thus, the RHS method should be supplemented with such assessment components that would enable characteristics of the hydrological regime, including the disruptions resulting from major changes in the development of the catchment area.

\section{REFERENCES}

[1] Raven P.J., Holmes N.T.H., Dawson F.H.\& Everard, M. Quality assessment using River Habitat Survey data. Aquatic Conservation, Marine and Freshwater Ecosystems, vol. 8, pp 405-424, 1998.

[2] Graf W. L. Downstream hydrologic and geomorphic effects of large dams on American rivers, Geomorphology, vol. 79, pp 336-360, 2006.

[3] Soja R. \& Wiejaczka Ł. The impact of a reservoir on the physicochemical properties of water in a mountain river, Water and Environment Journal, vol. 28, pp 473-482, 2014.

[4] Erba S., Buffagni A., Holmes N., O’Hare M., Scarlett P. \& Stenico, A. Preliminary testing of River Habitat Survey features for the aims of the WFD hydro-morphological assessment: an overview from the STAR Project, Hydrobiologia, vol. 566, pp 281-296, 2006.

[5] Wiejaczka Ł.\& Kijowska-Strugała M. Assessment of the hydromorphological state of Carpathian rivers above and below reservoirs, Water and Environment Journal, Poland, vol. 29, pp 277-287, 2015.

[6] Environment Agency. River Habitat Survey Guidance Manual: 2003 versio, Environment Agency, Bristol, 2003.

[7] Walker J., Diamond M. \& Naura M. The development of physical habitat objectives, Aquatic Conservation: Marine and Freshwater Ecosystems, vol. 12, pp 381-390, 2002.

[8] Jusik S., Bryl Ł., Przesmycki M.\& Kasprzak M. Ewolucja metody oceny stanu hydromorfologicznego rzek RHS-PL w Polsce, Inżynieria i Ochrona Środowiska, Polska, vol. 17, 2014. 